\section{Manuscript Details \\ Improving social impact assessment of Protected Areas: A review of the literature and directions for future research}

Nikoleta Jones, James McGinlay, Panayiotis Dimitrakopoulos

\title{
Abstract
}

Protected areas are the most widely applied policy tool for biodiversity conservation. However, effective management of protected areas is often obstructed by conflicts mainly associated with the social impacts imposed on local communities and other users by their establishment. Despite the importance of these social impacts they remain significantly under-researched. There is now an increasing need to incorporate social impacts in decision making processes by providing accurate estimations and develop ways to forecast their change in the future. Considering the increase of studies identifying this need, the present paper aims to indicate three main directions that will assist in designing effective tools for measuring and most importantly understanding social impacts: a) perceptions on social impacts of individuals who are directly affected by protected areas need to be incorporated in management evaluation techniques in a meaningful and accurate way and be combined with objective measurements of impact; b) understanding the factors determining the actual and perceived levels of social impacts is a key step for the design of effective management frameworks of protected areas and c) social impacts should not be seen as static concepts but should be seen as a dynamic and long-term factor which needs to be incorporated in decisionmaking processes.

Keywords protected areas; biodiversity; social capital; place attachment; social impacts 


\section{Improving social impact assessment of Protected Areas: A review of the literature}

and directions for future research

\section{Introduction}

Protected areas are of growing importance internationally due to the urgency in meeting biodiversity conservation targets and also because of their role in adaptation and mitigation of climate change impacts (Dudley et al., 2010; IUCN, 2012; Soares-Filho et al., 2010). In this context, the need to create new, and re-strengthen existing, legislative frameworks concerning Protected Areas (PAs) will become essential in the near future, both by the establishment of new PAs or through reconsideration of the boundaries of existing ones.

PAs are established in order to meet two main targets: to conserve biodiversity but also to provide society with ecosystem services, such as protection from flooding and food production (Dudley, 2008), as well as cultural ecosystem services through tourism and recreation (Church et al., 2014). In the present paper we aim to discuss social impacts assessment of PAs as this type of impacts are a major factor influencing social acceptability for conservation initiatives. Several factors have been identified explaining the reasons behind social acceptability and compliance with PA regulations (Adams et al., 2011; Gall \& Rodwell, 2016). The social impacts of some types of protected areas are a key topic in this discourse (Andrade \& Rhodes, 2012; Bennett \& Dearden, 2014; de Lange et al., 2016; Gall \& Rodwell, 2016; Voyer et al., 2012) as they represent the costs and benefits following the designation of a PA (Charles \& Wilson, 2009; Lowry et al., 2009; West et al., 2006). Apart from their physical composition, the effectiveness of PAs will depend on the willingness of communities (affected by their establishment) to comply with any new regulations imposed and their social impacts.

In our analysis we will focus on PAs where humans are significantly influenced by their establishment. In order to further explain this we need to briefly describe the main categories of PAs internationally. According to IUCN there are 6 main types: (Ia) Strict Nature Reserves which is the most restrictive type of PA regarding human activities; (Ib) Wilderness Areas where there are significant restrictions for humans but there has been also traditionally a limited impact by humans in the area; (II) National Parks which are usually large areas established in order to 'protect natural biodiversity along with its underlying ecological structure and supporting environmental processes, and to promote education and recreation'. This type of $\mathrm{PA}$ will often have zones where regulations resembling those of category Ia are enforced; (III) Natural Monuments or Feature Areas which are often small 
areas with a large number of visitors; (IV) Habitat/Species Management Areas which focus on the protection of a particular species or habitats and require intervention to secure successful protection; (V) Protected Landscape/ Seascape areas which are of significant value due to the unique interaction which has been developed between humans and nature; (VI) Protected areas with sustainable use of natural resources where biodiversity conservation targets are not the primary focus. The aim is to preserve the area along with local cultural values through a traditional resources management system. There are also 4 different types of management frameworks recognized by IUCN: Public (managed by the state), Private (governance by private owner or non-profit organisations), Shared governance (referring mainly to collaborative management frameworks) and PAs governed by indigenous people and local communities. Social impacts are expected to be more evident in 'strict' management frameworks, such as Strict Nature Reserves which impose significant restrictions on local populations as all activities are prohibited in the specific geographical area and also National Parks. In the latter case due to the large size of national parks and their multiple aims in terms of biodiversity conservation it is expected that their establishment will affect a variety of local uses, increasing potential conflicts. On the contrary, wilderness areas are those where there has been very limited intervention by humans and Natural monuments are often very small areas where the focus is on tourists and protected landscape designation does consider the co-existence of local communities within the specific landscape. Regarding the different management frameworks, in our analysis we will focus mainly on public and shared governance of PAs as these are frameworks where there is a clear influence from a top-down mechanism in the formation of social impacts.

Although the discussion around social impacts of PAs has significantly increased in the past decade and several methods have been proposed incorporating the assessment of PAs' impacts in policy-making processes (Franks \& Small, 2016; Leverington et al., 2010; Schreckenberg et al., 2010; Tempesta \& Otero, 2013) they remain one of the most underrepresented topic in the field of biodiversity conservation (Voyer et al., 2012). This is a gap that has been recognised in the Social Impact Assessment (SIA) literature where often in large projects there is a 'technical and technocratic focus' with non-technical issues such as social being given limited attention (Vanclay et al., 2015).

In this paper we take a closer look at social impacts of PAs, focusing on the specific types of PAs mentioned above, and we discuss three main challenges in this process. Firstly, we propose the need to develop evaluation frameworks which focus both on subjective and objective measurements of social impacts. These refer both to the impacts as these are 
perceived by communities affected by the designation of a PA combined with more 'objective' measurements allowing the detailed observation of social impacts. Secondly, we emphasize the need to develop a framework explaining the numerous factors influencing the level of social impacts. Finally, we propose that social impacts should not be seen as static concepts but as a dynamic and long-term factor which needs to be incorporated in decisionmaking processes.

\section{Social impacts of PAs}

\subsection{Social impacts}

Social impact refers to 'the consequences to human populations of any public or private actions that alter the ways in which people live, work, play, relate to one another, organize to meet their needs and generally cope as member of the society' (Burdge et al., 1995). These social impacts can refer to a variety of issues such as the change on 'Peoples' way of life, their culture, their community (and its' cohesion), their political systems, their environment, their health and well-being, their personal and property rights, their fears and aspirations' (Vanclay, 2003). In the Ecosystem Services literature, social impacts are often included under the wider umbrella of well-being and according to the Millennium Ecosystem Assessment (2005) there are five determinants constituting well-being linked with ecosystem services: a) security, b) basic material for a good life, c) health, d) good social relations and e) freedom of choice and action; each one including several sub-categories.

In the next paragraphs we will analyse the main impacts that have been presented through case studies and theoretical discussions in the literature of biodiversity conservation and social impact assessment. We start our analysis based on the fundamental argument that the most important change that a PA establishment brings (especially in the case of National Parks and Strict Nature Reserves) is the imposition of a new management framework where new regulations in relation to the natural resources and infrastructure are imposed (Ghimire \& Pimbert, 2000; Stevenson et al., 2013; Charles \& Wilson, 2009; Rees et al., 2013).

\section{Poverty}

Poverty levels are influenced by PAs mainly due to the development of tourist and recreational activities and the change in the use of natural resources (Ferraro \& Hanauer, 2014). Three main categories of impacts have been identified in the literature relating to 
132 poverty: security, opportunity and empowerment (Gurney et al., 2014). Although concerns

133 have been raised in the literature that PAs can significantly affect local communities

134 financially in a negative way (Eneji et al., 2009), there is strong and recent evidence that PAs

135 can contribute to the reduction of poverty levels in local communities (Ferraro \& Hanauer,

136 2014; Canavire-Bacarreza \& Hanauer, 2012; Clements et al., 2014). The establishment of a

137 PA often implies significant positive impacts on employment (Cernea \& Schmidt-Soltay,

138 2006) through the creation of new job opportunities such as personnel for the protection of

139 the area, staff for environmental management projects and also new jobs linked with

140 recreational activities and eco-tourism. Furthermore, the production and sale of traditional

141 products is also a major additional source of income in several PAs promoting traditional

142 uses of natural resources.

143 provide to communities. The main aim of a PA, the protection of the environment, can be considered one of the most important social benefits for local communities (Charles \& Wilson, 2009; Coad et al., 2008) as it can increase quality of life. An effective protected area implies a healthy ecosystem, which means access to resources of good environmental quality for local communities (Corvalan et al., 2005), such as safe drinking water (Dudley \& Stolton, 2003). Furthermore, there is evidence that effective PAs can assist in a 'higher energy and protein intake' for local communities (Aswani \& Furusawa, 2007). However, there is also evidence that PAs can have health 'costs' as access to natural resources essential for the nutrition of local populations can be restricted (Ferraro, 2002). For example, in the study of Gjertsen (2005) a restrictive management framework is described where fines were imposed on locals who attempted to access natural resources in order to feed their families and as a result there was a negative impact on their health.

\section{Displacement}

A significant social impact of several major projects is displacement (IASA, 2015). In PAs displacement can be voluntary, forced or induced (Lasgorceix \& Kothari, 2009) and can have accompanying risks such as marginalisation of certain groups and loss of income (Cernea \& Schmidt-Soltau, 2006; Brockington \& Wilkie, 2015), change in the distribution of powers and relocation of access and management rights (Mascia \& Claus, 2008). Despite these significant impacts currently there are no specific guidelines on how to address 
displacement of PAs (Agrawal \& Redford, 2009). However, recent IASA propositions include a Resettlement Policy Framework that needs to be in place in order to facilitate the implementation of a large project (Vanclay et al., 2015), such as the designation of a PA.

\section{Re-distribution of power}

The designation of a PA often implies the application of a new management framework and with this change often there is also a re-distribution of power in the area and the formation of alliances between different entities affected by the PA (Celata \& Sanna, 2012). A change in the distribution of power will define the impact on well being and the sense of (in)justice developed especially when local people consider that the restrictions imposed are not equally distributed among them (Hattam et al., 2014; Kellert et al., 2000). Such issues can aggravate social conflicts between local stakeholders (Bennett \& Dearden, 2014; Hattam et al., 2014). It should be noted that this impact will be significantly determined by the type of management framework applied with a general agreement in the literature that comanagement frameworks where locals are involved in decision making processes can assist in a higher level of compliance (Andrade \& Rhodes, 2012).

\section{Human Rights}

The establishment of PAs can have a significant impact on human rights of local communities as it affects 'customary laws and traditional institutions, customary rights to their territories, lands, waters, natural resources, and knowledge systems' (Makagon et al., 2014). Indicative categories of human rights affected are economic, social and cultural as well as civil and political (Pullin et al., 2013). Although it is widely accepted that conservation initiatives can have significant impact on human rights they have not been incorporated widely in impact assessment for PAs. Human Rights Impact Assessment (HRIA) however has been increasingly recognised as an important tool, especially for private projects from businesses (Kemp \& Vanclay, 2013; Esteves et al., 2012) such as mining (Boele \& Crispin, 2013), and could be adapted by PAs. Useful lessons that can be learned from HRIAs are on the methods measuring this impact and the process of evaluation (Boele \& Crispin, 2013) including the shared understanding and prioritization of human rights.

\subsection{Assessing social impacts of PAs}

Studies and methodological approaches measuring social impacts of ecosystems services have significantly increased in the past decade (de Lange et al., 2016; Franks \& Small, 2016; 
200

201

202

203

204

205

206

207

208

209

210

211

212

213

214

215

216

217

218

219

220

221

222

223

224

225

226

227

228

229

230

Ervin, 2003; Stolton et al., 2007). Table 1 lists the most commonly used methodologies which have been applied in either the original or an adapted form to assess impacts on individual PA sites and networks of PAs. Most are focused on informing a system of adaptive or responsive management for specific PA sites (Cifuentes et al., 2000; Corrales 2004; Pomeroy et al., 2004; Staub \& Hatziolos 2004; Stolton et al. 2007; Hockings et al.2008) whilst a few, such as Ervin (2003), are focused more on a system-wide analysis. Specific methods proposed within the broader methodologies range from desk studies and rapidscoring assessments by management stakeholders, through to more detailed data gathering such as distribution of questionnaires, household surveys, semi-structured interviews, focus groups and workshops. Thus, data gathered may be quantitative, semi-quantitative or qualitative (de Lange et al., 2016; Oldekop et al., 2016).

Despite the increase of studies focusing on social impact assessment (Vanclay et al, 2015), currently there is no official protocol or widely accepted standard tool in order to assess social impacts of PAs in particular. In our view, there are two main issues causing this. First, defining social impacts indicators is an extremely challenging task and it is a field which is constantly developed both in the ecosystem services literature (de Lange et al., 2016; Oldekop et al., 2016) but also in the field of impact assessment (Vanclay et al., 2015). A second issue is that social impacts can be measured both in an objective way (e.g increase of employment in the area) but also in a subjective way (e.g. perceptions of local communities on the change of their well being). In large-scale data collection studies, social impacts are often only investigated, if at all, from the perspective of the management actor thus providing a more objective measurement (e.g. Staub \& Hatziolos, 2004; Stolton et al., 2007; Vokou et al., 2014). In some cases, very brief and general guidelines are provided for their exploration based on citizens' perceptions (Tempesta \& Otero, 2013; Stolton et al., 2007; Pomeroy et al., 2004). Thus, the treatment of social impacts may be somewhat cursory or partial in the deployment of methodologies in a site-specific context. Table 2 provides an overview of the main categories of indicators used by such assessment methodologies to identify and evaluate socio-economic and cultural impacts of PAs.

Table 1. Commonly-used evaluation frameworks incorporating social impact assessment in their measurement

Measurement framework Reference 
EoH Enhancing our heritage

METT Management effectiveness tracking tool

How is your MPA doing?

World Bank MPA score card

Rapid evaluation of management effectiveness

in marine protected areas of Mesoamerica

RAPPAM Rapid assessment and prioritization of protected area management
Hockings et al. (2008)

Stolton et al. (2007)

Pomeroy et al. (2004)

Staub and Hatziolos (2004)

Corrales (2004)

Ervin (2003)

Cifuentes et al. (2000)

231

232

233 
Table 2. Social Impacts of PAs: broad indicator themes and example studies and methodologies considering them

Impact indicators

\begin{tabular}{|c|c|}
\hline $\begin{array}{l}\text { Income, Employment and } \\
\text { monetary wealth }\end{array}$ & $\begin{array}{l}\text { Cernea \& Schmidt-Soltau, 2006; Foerster et al., 2011; Oldekop } \\
\text { et al., 2016; Mascia et al., 2010; Ervin, 2003; Staub \& } \\
\text { Hatziolos, 2004; Hockings et al., 2008; Pomeroy et al., } 2004 \\
\text { Stolton et al., 2007; Stuhsaker, } 2005\end{array}$ \\
\hline $\begin{array}{l}\text { Landlessness \& } \\
\text { Homelessness }\end{array}$ & Cernea \& Schmidt-Soltau, 2006 \\
\hline Poverty & $\begin{array}{l}\text { Garney et al. 2014; Canavire-Bacarreza \& Hanauer, 2012; } \\
\text { Brockington \& Wilkie, 2015; Daw et al., 2011; Foerster et al., } \\
2011\end{array}$ \\
\hline $\begin{array}{l}\text { Conflicts and conflict } \\
\text { management }\end{array}$ & Oldekop et al., 2016 \\
\hline Access to natural resources & Cernea \& Schmidt-Soltau, 2006; Oldekop et al., 2016 \\
\hline Quality of life & Jones et al., 2012; Pomeroy et al., 2004; Courrau, 2005 \\
\hline Empowerment & Oldekop et al., 2016; Gurney et al., 2014 \\
\hline Equity and social justice & $\begin{array}{l}\text { Banini et al., 2006; Pomeroy et al., 2004; Staub \& Hatziolos, } \\
\text { 2004; Struhsaker et al., } 2005\end{array}$ \\
\hline $\begin{array}{l}\text { Culture and Cultural } \\
\text { relationships }\end{array}$ & $\begin{array}{l}\text { Leverington et al., 2010; Ervin, 2003; Pomeroy, 2004; Staub \& } \\
\text { Hatziolos, 2004; Stolton et al., 2007; Cifuentes et al., , 2000; } \\
\text { Leverington et al., 2008; Courrau, } 2005\end{array}$ \\
\hline $\begin{array}{l}\text { Engagement \& } \\
\text { communication }\end{array}$ & $\begin{array}{l}\text { Wells and Mangubhai, 2004; Stolton et al.., 2007; Pomeroy et } \\
\text { al., 2004; Staub \& Hatziolos, 2004; Hockings et al., } 2006\end{array}$ \\
\hline Local values and beliefs & Pomeroy et al., 2004 \\
\hline Social structure and trust & $\begin{array}{l}\text { Courrau, 2005; Hockings et al., 2006; Pomeroy et al., 2004; } \\
\text { Staub \& Hatziolos, 2004; Stolton et al., 2007; Foerster et al., } \\
2011\end{array}$ \\
\hline $\begin{array}{l}\text { Economic and Physical } \\
\text { Displacement }\end{array}$ & $\begin{array}{l}\text { Brockington et al., 2008; Oldekop et al., 2016; Brockington \& } \\
\text { Wilkie, 2015; Hockings et al., 2008; Pomeroy et al., 2004; } \\
\text { Courrau, 2005; Corrales, } 2004\end{array}$ \\
\hline Health & er et al., 2013; Mascia \& \\
\hline
\end{tabular}




\section{Challenges and directions for future research}

\subsection{Measuring social impacts}

A key question when measuring social impacts of PAs concerns how to measure them. There are three different ways that this can be achieved. First, data can be obtained regarding the impact of the PA on the total population focusing on issues such as employment and nutrition. Second, social impacts can be measured based on the perceptions of the management actor. Thus, apart from the more objective measurements mentioned above, members of the management authority can be asked to evaluate the impact on the local population based on their experience. A third way is to focus on perceptions of local communities and explore what impact does the PA has on their lives on issues such as well being, quality of life and their everyday activities.

Up until recently most large scale studies and evaluation methodologies for PAs focused on social impacts which can be measured through secondary data or indicators which are reported by the management actor of the PA (e.g. Staub \& Hatziolos 2004; Stolton et al.2007). In some cases, very brief and general guidelines were provided for their exploration based on citizens' perceptions (Pomeroy et al. 2004; Stolton et al. 2007; Tempesta \& Otero 2013). However, measuring social impacts based on the management actors' perceptions, can be somewhat cursory or partial in the deployment of methodologies in a site-specific context (Paleczny \& Harhash 2007). The development of social impacts of PAs that are based on perceptions of citizens affected, are equally, or even more, important to be assessed (Vanclay 2012) and assessment of social impacts through a participatory process is considered a significant requirement for Social Impact Assessments techniques (Esteves et al. 2012; Nzeadibe et al., 2015).

There is now a growing body of literature measuring aspects of social impacts of PAs based on local communities' perceptions and emphasizing the value of this information for biodiversity conservation (Stevenson et al., 2013). Thus we claim here that it is crucial for future policy decisions for PAs to measure social impacts taking into consideration both 
subjective and objective measurements. The incorporation of data measuring social impacts based on the perceptions of those who are affected by the designation is crucial and factors influencing these perceptions should also be taken into consideration.

\subsection{Understanding how perceptions on social impacts are formed}

The measurement of social impacts based on citizens' perceptions brings an additional challenge. Differences are expected between individuals' perceptions, making the interpretation of these impacts even harder when compared to environmental (e.g. change in species) or economic (e.g. income level) indicators. These differences can occur even when we are exploring them in the context of the same management framework. An indicative example are National Parks across Europe where there are sites with similar management frameworks established in different parts of Europe (often state management or some type of participatory management with local stakeholders). However, the impact of these sites, as these are perceived by citizens, will not be the same across European states. The key point here is that the level of social impacts perceived will significantly depend on the socioeconomic context in which the PA is designated and the cultural differences among people of different countries on nature conservation. Future research should focus in the identification of these explanatory factors as they are expected to influence social acceptability for biodiversity conservation projects, similarly to social license for private projects (Dare et al., 2014).

Although this is clearly an emerging field we would like to propose here a list of factors proposed in the fields of social impact assessment and environmental social science which can assist in the understanding of how social impacts are formulated. Several demographic factors are expected to influence social impacts as perceived by citizens. Gender is one of them (Coad et al., 2008), mainly because differences in use and power may mean that there will be different impacts between men and women. Communities connected with a protected area are often composed of different ethnic groups, which vary in their use of the resource, tenure rights and power (Coad et al., 2008). Furthermore, the economic circumstances that exist in a region are also likely to influence the way these impacts are perceived by citizens (Coad et al., 2008). The location of the community is also expected to influence perceptions (Karki, 2013). Specifically, the perceived benefits will be influenced by how close a community is to the new benefits, such as new facilities, provided by a PA (Ezebilo \& Mattsson, 2010). Other demographic factors that may affect perceptions towards impacts refer to age, education and household characteristics (Karki, 2013). 
A recent development in the PA literature is the identification of links with social capital issues (Jones et al., 2012, Gutierrez et al., 2011). Several elements have been considered as components of social capital in the literature, those commonly used in international studies being social trust, institutional trust, social networks and social norms (Putnam et al., 1993; Coleman, 1990; Adger, 2003; Pretty, 2003). Social capital has a significant influence on the level of social impacts perceived by local communities and also on the level of public acceptability of public policies (Jones \& Clark, 2014; Jones et al., 2015, 2012). This is mainly because in communities with low levels of trust (both institutional and social) individuals regard proposed public policy measures as ineffective and perceive higher impacts from the application of such policies. Thus, introducing policies demanding a significant change by local people will also be seen as imposing increased negative social impacts on them. Equally important are local values and beliefs (Pomeroy et al, 2004; Loxton et al., 2013). Depending on whether local values 'support' or not the establishment of a PA and its' causes they will also influence perceptions on social impacts (Loxton et al., 2013). Furthermore, social networks are expected to influence the type and flow of information and as a result will have an impact on perceptions for the necessity of public policy intervention and its possible consequences (Wolf et al., 2010; Jones \& Clark, 2014).

Place attachment is another important factor influencing citizens' perceptions and public acceptability of environmental strategies (emotional bonds and place related symbolic meanings) (Devine-Wright, 2011). The opposition of citizens towards specific policies can be conceived as a 'place-protective action' (Devine-Wright, 2009). In the case of PAs, the geographical area where a PA is created has a specific value for the local community (Pomeroy et al., 2004; Charles \& Wilson, 2009) and this value is expected to have an influence on the impacts that are connected with the PA (Pomeroy et al., 2004). In the context of this parameter, tenure rights and uses of the resources included in the PA should also be taken into consideration (Coad et al., 2008). This is mainly because the social costs and benefits from the designation of a PA are expected to be different depending on the use of a resource by individuals in a community and this will also have an effect on the value that individuals have for a specific place.

Several frameworks have also been developed in the past decades aiming to understand the relationship between humans and nature and the reasons influencing humans' attitudes towards the natural environment. Indicative examples include the New Ecological Paradigm (Dunlap et al., 2000), the Environmental Identity Scale (Clayton, 2003) and the Nature Relatedness Scale (Nisbet et al., 2008). Thus additional factors which need to be taken into 
consideration when exploring the formation of perceptions on social impacts include connectedness to nature (Gosling \& Williams, 2010), past experiences (Kals et al., 1999) and pro-environmental attitudes (Carrus et al., 2005).

Level of awareness about the PA and satisfaction with, or approval of, its presence is expected to also have an impact on individuals' perceptions (Courrau, 2005; Tempesta \& Otero, 2013; Staub \& Hatziolos, 2004). Similarly, environmental education initiatives and awareness of their own responsibilities in the context of a conservation policy will also have an impact (Tempesta \& Otero, 2013; Courrau, 2005; Rees et al., 2013; Stolton et al., 2007; Nisbet et al., 2011). Based on theoretical assumptions (Jones \& Clark, 2013) higher levels of environmental awareness can lead to lower perceived costs, as citizens recognise the multiple benefits of a proposed policy and the subsequent socio-economic benefits. It should also be noted that the level of awareness is expected to have a clear link with social networks, as a parameter of social capital, as these provide the main source of information for environmental issues (Wolf et al., 2010).

Finally, the Management framework of the $\mathbf{P A}$ is also expected to influence perceptions on social impacts. There are different management frameworks that can be applied when designating a PA. The main distinction as mentioned in the introduction of the paper is between public, private, co-managed and PAs managed by indigenous people and local communities. There is significant evidence that co-management frameworks can be very effective and can lead to an increase of the benefits for the local community from the establishment of a PA (Stoll-Kleemann et al., 2010), such as empowerment and monetary benefits (Oldekop et al., 2016). A collaborative management framework assists in the inclusion of people in decision-making (Berkes, 2004) promoting the principles of equity and fairness while assisting in the organisation of local communities and the promotion of ‘common property regimes’ (Bennett \& Dearden, 2014). Thus an increased engagement can lead to 'obtaining' a social license for projects, such as PAs, to operate (Dare et al, 2014). However, the influence of the management framework on social impacts may not be so straightforward considering the fact that co-management does impose certain costs on the community as it necessitates public engagement (Jones et al., 2012). Furthermore, the influence of the management framework on social impacts will also be affected by the level and type of recreational and cultural activities developed (Coad et al., 2008; Sims, 2010; Bennett \& Dearden, 2014; Charles \& Wilson, 2009; Hattam et al., 2014). Despite the importance of the management framework currently there are very limited studies exploring whether social impacts are lower when co-management frameworks are applied, revealing the 
need to conduct comparative studies in order to explore the impact of the management framework on social impacts.

\subsection{Exploring the change of social impacts through time}

A final point we would like to underline in the paper is that social impacts are not static concepts but are expected to change over time(de Lange et al., 2016; Gurney et al., 2014; Ferraro et al., 2015). Currently no large-scale longitudinal survey exists exploring the change of social impacts through time. Dudley et al. (2007) suggests that if improvements in the management framework are implemented through time then this will affect a PAs effectiveness, in line with the model of adaptive or responsive management. There has also been some limited empirical evidence that time is linked with effectiveness of Marine PAs (Vandeperre et al., 2011), reduction of poverty (Canavire-Bacarreza \& Hanauer, 2012) and also short-term positive impacts on poverty (Gurney et al., 2014). However, we have no clear evidence how time interacts with social impacts especially in relation to how these are perceived by citizens. Thus, there is no proof if increased effectiveness is due to higher compliance and if compliance is linked to a reduction in the negative social impacts along with an increase of benefits.

This is a crucial area of investigation for environmental policy planning and implementation processes and it is linked with the issue of social acceptability. Its importance rests mainly on the fact that when measuring social impacts, when a policy is initially implemented, it is useful to be able to predict the change of these impacts over time. Reframing any area as a primarily 'natural' space will start a process to reshape other aspects of the space: cultural, social and economic. An application of a very restrictive policy for example is expected to initially raise significant concerns among locals and as a result an assessment of social impacts at that stage would emphasize the negative social impacts for local communities. However, the level of acceptability even for some very restrictive policies can change through time, especially when the benefits of the policy become more apparent for local communities and also when the new regulations become part of the everyday habits of people. From the methodologies explored in this study, none had incorporated as an objective to undertake an initial baseline assessment (measuring individual perceptions) either before or during the designation of the PA against which to assess subsequent change. Without such research, some changes, perhaps the most significant, may not be captured by an assessment exercise. 


\section{Conclusion}

The aim of this paper was to highlight certain issues that need to be addressed and taken into consideration in the future in order to improve social impact assessment of Protected Areas. In particular, we focused on three main challenges: the incorporation of both local subjective perceptions as well as potentially more objective indicators in social impact assessment for PAs; the impact of certain factors on citizens' responses to and perceptions of these impacts; and the change of social impacts through time. Addressing these issues is a challenging task that requires the re-consideration of current techniques assessing social impacts of PAs. Based on our analysis we regard as necessary that a methodology should be developed which can be applied in different areas allowing the estimations of social impacts while permitting the comparison of impacts between different protected areas. Furthermore, social impact assessment techniques for PAs need to incorporate the opinions of different stakeholders including the users of the PAs. In the context of such studies different factors influencing these perceptions can be measured explaining the level of social impacts as these are perceived by different social groups. In addition, we propose that social impact assessment for PAs should be periodically repeated. By observing the change in social impacts through time significant information can be provided regarding the role of the PA for local communities and the change in the geographical space which is designated as a nature reserve. Assessing social impacts prior to implementation and monitoring them after the designation of a PA will provide valuable information for decision-makers in order to achieve a balance between biodiversity conservation and socio-economic justice.

\section{References}

Adams V.M., Mills M., Jupiter S.D., Pressey R.L. 2011. Improving social acceptability of marine protected area networks: A methods for estimating opportunity costs to multiple gear types in both fisged and currently unfished areas. Biol. Conserv., 144, 350-361.

Adger, W.N. 2003. Social Capital, Collective Action, and Adaptation to Climate Change. Econ. Geog., 79, 387-404.

Agrawal, A., Redford, K., 2009. Conservation and Displacement: An overview. Conserv. Soc., 7, 1-10.

Andrade, G.S.M., Rhodes, J.R. 2012. Protected Areas and communities: An inevitable partnership towards successful conservation strategies. Ecol. Soc., 17, 14. 
Aswani, S., Furusawa, T. 2007. Do Marine Protected Areas Affect Human Nutrition and Health? A Comparison between Villages in Roviana, Solomon Islands. Coastal Manage., 35, 545-565.

Banini S., Marino D., Lumaca C., Addis D., Alborino N., Marucci A., Palmieri M., Parasacchi A., Soffietti E., Zaottini D., Zarlenga G. 2006. Assessment of Protected Areas Management Effectiveness” Report phase ${ }^{\circ} 1$ CUEIM - Ministero dell’Ambiente e Tutela del territorio e del mare.

Bennett, N.J., Dearden P. 2014. Why local people do not support conservation: Community perceptions of marine protected area livelihood impacts, governance and management in Thailand. Mar. Policy, 44, 107-116.

Berkes, F. 2004. Rethinking Community-Based Conservation. Conserv. Biol., 18, 621630.

Boele R., Crispin C. 2013. What direction for human rights impact assessment? Impact Assess. Proj. Apprais., 31, 128-134.

Brockington, D, Duffy, R., Igoe, J. 2008. Nature Unbound: Conservation, Capitalism and the Future of Protected Areas: The Past, Present and Future of Protected Areas. London: Earthscan.

Brockington D., Wilkie D. 2015. Protected areas and poverty. Philos. T. Roy. Soc. B, 370, DOI: $10.1098 /$ rstb.2014.0271

Burdge, R.J., Fricke, P., Finsterbusch, K., Freudenburg, W.R., Gramling, R., Holden, A., Llewellyn, L., Petterson, J.S., Thompson, J., Williams, G. (Interorganizational Committee on Guidelines and Principles for Social Impact Assessment). 1995. Guidelines and Principles for Social Impact Assessment. Environ Impact Asses., 15, 11-43.

Carrus G., Bonaiuto M., Bonnes M. 2005. Environmental concern, regional identity and support for protected areas in Italy, Envir Behav, 37, 237-257.

Celata, F., Sanna, V.S. 2012. The post-political ecology of protected areas: nature, social justice and political conflicts in the Galapagos Islands. Local Environment, The International Journal of Justice and Sustainability, 17, 977-990

Cernea, M.M. and K. Schmidt-Soltau. 2006. Poverty risks and national parks: Policy issues in conservation and resettlement. World Dev., 34, 1808-1830.

Charles, A., Wilson, L. 2009. Human dimensions of Marine Protected Areas. ICES J. Mar. Sci., 66, 6-15.

Church, A., Fish, R., Haines-Young, R., Mourato, S., Tratalos, J., Stapleton, L., Willis, C., Coates, P., Gibbons, S., Leyshon, C., Potschin, M., Ravenscroft, N., Sanchis-Guarner, R., 
Winter, M., Kenter, J. 2014. UK National Ecosystem Assessment Follow-on. Work Package Report 5: Cultural ecosystem services and indicators. UNEP-WCMC, LWEC, UK

Canavire-Bacarreza, G., Hanauer, M.M. 2012. Estimating the impacts of Bolivia's Protected Areas on Poverty. World Dev., 41, 265-285.

Cifuentes M., Izurieta A. de Faria H. 2000. Measuring protected area management effectiveness. Turrialba (Costa Rica): WWF Centroamerica.

Clements, T., Suon, S., Wilkie, D.S., Milner-Gulland, E.J. 2014. Impacts of Protected Areas on Local Livelihood, World Dev., 64, S125-s134.

Coad, L, Campbell, A, Miles, L., Humphries, K. 2008. The Costs and Benefits of Protected Areas for Local Livelihoods: a review of the current literature. Working Paper. Cambridge, U.K: UNEP World Conservation Monitoring Centre

Corvalan C., Hales S., McMichael A (core writing team) 2005. Ecosystems and human well-being: health synthesis: a report of the Millennium Ecosystem Assessment. World Health Organisation.

Corrales, L. 2004. Manual for the Rapid Evaluation of Management Effectiveness in Marine Protected Areas of Mesoamerica. Guatemala City: PROARCA/APM

Courrau, J. 2005. Monitoring and Assessment with Relevant Indicators of Protected Areas of the Guianas MARIPA -G. Guianas Forests \& Environmental Conservation Project WWFGUIANAS

Dare M.L., Schirmer J., Vanclay F. 2014. Community engagement and social licence to operate. Impact Assess. Proj. Apprais., 32, 188-197.

Daw, T., Brown, K., Rosendo, S., Pomeroy, R. 2011. Applying the ecosystem services concept to poverty alleviation: The need to disaggregate human well being. Working Paper 30, DEV Working Paper Series, The School of International Development, University of East Anglia, UK.

De Lange, E., Woodhouse, E., Milner-Gulland, E.J. 2016. Approaches used to evaluate social impacts of protected areas. Conserv. Lett., DOI: 10.1111/conl.12223

Devine-Wright, P. 2009. Rethinking NIMBYism: The role of place attachment and place identity in explaining place-protective action. J. Comm. App. Soc., 19, 426-441.

Devine-Wright P. 2011. Enhancing Local Distinctiveness Fosters Public Acceptance of Tidal Energy: A UK Case Study. Energy Policy, 39, 83-93.

Dudley, N., Belokurov, A., Higgins-Zogib, L., Hockings, M., Stolton, S., Burgess, N. 2007. Tracking progress in managing protected areas around the world. An analysis of two applications of the Management Effectiveness Tracking Tool developed by WWF and the 
World Bank. WWF International, Switzerland.

Dudley, N. 2008. Guidelines for Applying Protected Area Management Categories. Gland, Switzerland: IUCN.

Dudley N., Stolton S., 2003. Running Pure. The importance of forest protected areas to drinking water. A research report by the World Bank / WWF Alliance for Forest Conservation and Sustainable Use.

Dudley, N, Stolton, S, Belokurov, A, Krueger, L, Lopoukhine, N, MacKinnon, K, Sandwith, T, Sekhran, N. 2010. Natural Solutions: Protected areas helping people cope with climate change, IUCNWCPA, TNC, UNDP, WCS, The World Bank and WWF, Gland, Switzerland.

Eneji, V.C.O., Gubo, Q., Okpiliya, F.I., Aniah, E.J., Eni, D.D., Afangide, D. 2009. Problems of public participation in biodiversity conservation: the Nigerian scenario. Impact Assess. Proj. Apprais., 27:4, 301-307, doi: 10.3152/146155109X479431

Ervin, J. 2003. Rapid Assessment and Prioritization of Protected Area Management (RAPPAM) Methodology. Gland, Switzerland: WWF.

Esteves, A.M., Franks, D., Vanclay, F. 2012. Social impact assessment: the state of the art. Impact Assess. Proj. Apprais., 30, 34-42.

Ezebilo, E.E., Mattsson, L. 2010. Socio-economic benefits of protected areas as perceived by local people around Cross River National Park, Nigeria. For. Policy Econ. 12, 189-193.

Ferraro P.J. 2002. The local costs of establishing protected areas in low-income nations: Ranomafana National Park, Madagascar. Ecol. Econ., 43, 261-275.

Ferraro P.J., Hanauer M.M., 2014. Quantifying causal mechanisms to determine how protected areas affect poverty through changes in ecosystem services and infrastructure. Proc. Natl. Acad. Sci. U.S.A, 111, 4332-4337.

Ferraro P.J. \& Pressey R.L. 2015. Measuring the difference made by conservation initiatives: protected areas and their environmental and social impacts. Phil Trans R. B, 370, http://dx.doi.org/10.1098/rstb.2014.0270

Foerster S., Wilkie D.S., Morelli G.A., Demmer J., Starkey M., Telfer P., Steil M. 2011. Human livelihoods and protected areas in Gabon: a cross-sectional comparison of welfare and consumption patterns. Oryx, 45, 347-356

Franks, P., Small, R. 2016. Social Assessment for Protected Areas (SAPA). Methodology Manual for SAPA Facilitators. IIED, London

Gall, S.C., Rodwell, L.D. 2016. Evaluating the social acceptability of Marine Protected Areas. Mar. Policy, 65, 30-38. 
Gjertsen H. 2005. Human well-being? Evidence from Marine Protected Areas in the Philippines. World Dev., 33, 199-217.

Gosling E., Williams K.J.H. 2010. Connectedness to nature, place attachment and conservation behaviour: testing connectedness theory among farmers. J. Environ. Psychol., 30, 298-304.

Gurney G.G., Cinner J., Ban N.C., Pressey R.L., Pollnac R., Campbell S.J., Tasidiawa S., Setiawan F. 2014. Poverty and protected areas: An evaluation of marine integrated conservation and development project in Indonesia. Global Environ. Chang., 26, 98-107.

Gutierrez, N.L., Hilborn, R., Defeo, O. 2011. Leadership, social capital and incentives promote successful fisheries. Nature, 470, 386-389.

Hattam, C.E., Mangi, S.C., Gall, S.C., Rodwell, L.D. 2014. Social impacts of a temperate fisheries closure: understanding stakeholder's views. Mar. Policy, 45, 269-278.

Hockings, M., James, R., Stolton, S., Dudley, N., Mathur, V., Makombo, J. et al. 2008. Enhancing our Heritage Toolkit: Assessing management effectiveness of natural World Heritage sites. Paper 23. Paris: UNESCO.

IUCN. (2012). The role of protected areas in regard to climate change, scoping study Georgia. IUCN

Jones, N., Clark, J.R.A., Panteli, M., Proikaki, M., Dimitrakopoulos, P.G. 2012. Local social capital and the acceptance of Protected Area policies: An empirical study of two Ramsar river delta ecosystems in northern Greece. J. Environ. Manage., 96, 55-63.

Jones, N., Clark, J.R.A. 2013. Social capital and climate change mitigation in coastal areas: A review of current debates and identification of future research directions. Ocean Coast. Manage., 80, 12-19.

Jones, N., Clark, J.R.A. 2014. Social capital and the public acceptability of climate change adaptation policies: A case study in Romney Marsh, UK. Climatic Change, 123, 133145.

Kals, E., Schumacher, D., \& Montada, L. 1999. Emotional affinity toward nature as a motivational basis to protect nature. Envir Behav, 31, 178-202.

Karki, S.T. 2013. Do protected areas and conservation incentives contribute to sustainable livelihoods? A case study of Bardia National Park, Nepal. J. Environ. Manage., 128, 988-999.

Kellert SR., Mehta J.N., Ebbin S.A., Lichtenfeld L.L. 2000. Community natural resource management: Promise, Rhetoric and reality. Soc. Natur. Resour., 13, 705-715;

Kemp D., Vanclay F. 2013. Human rights and impact assessment: clarifying the connections in practice. Impact Assess. Proj. Apprais.,31, 86-96. 
Lasgorceix A., Kothari A., 2009. Displacement and relocation of protected areas: A synthesis and analysis of case studies. Economic and Political weekly

Leisher C., Samberg L.H., van Beukering P., Sanjayan M., 2013. Focal areas for measuring the human well-being impacts of a conservation initiative. Sustainability, 5, 9971010

Leverington, F., Costa, K.L., Courrau, J., Pavese, H., Nolte, C., Marr, M. et al. 2010. Management effectiveness evaluation in protected areas - a global study. Second edition. Brisbane AUSTRALIA: The University of Queensland.

Leverington, F., Hockings, M., Lemos-Costa, K. 2008. Management effectiveness evaluation in protected areas: Report for the project 'Global study into management effectiveness evaluation of protected areas', The University of Queensland, Gatton: IUCN WCPA, TNC, WWF, AUSTRALIA.

Lowry, G.K., White, A.T., Christie, P. 2009. Scaling Up to Networks of Marine Protected Areas in the Philippines: Biophysical, Legal, Institutional, and Social Considerations. Coast. Manage., 37, 274-290.

Loxton E.A., Schirmer J., Kanowski P. 2013. Exploring the social dimensions and complexity of cumulative impacts: a case study of forest policy changes in Western Australia. Impact Assess. Proj. Apprais., 31, 52-63, doi: 10.1080/14615517.2012.755353

Makagon J.E., Jonas H., Roe D., 2014. Human rights Standards for conservation (Part I):

593

594

595

596

597

598

599

600

601

602

603

604

605 606 To which conservation actors do International Standards Apply? IIED Discussion Paper, IIED, London

Mascia M.B., Claus C.A. 2008. A property rights approach to understanding human displacement from protected areas: the case of Marine Protected Areas. Conserv. Biol., 23, 16-23.

Mascia MB, Claus C., Naidoo R. 2010. Impact of marine protected areas on fishing communities. Conserv. Biol. 24, 1424-1429;

Millennium Ecosystem Assessment (2005) Ecosystems and Human Well-being: Synthesis. Island Press, Washington, DC.

Nisbet E.K., Zelenski J.M., Murphy S.A. 2008. The Nature Relatedness Scale, Linking Individuals' connection with nature to environmental concern and behaviour. Envir Behav, 41, 715-740

Nisbet K., Zelenski J. M., Murphy S. A., 2011. Happiness is in our Nature: Exploring Nature Relatedness as a Contributor to Subjective Well-Being. J. Happiness Stud., 12, 303322 
Nzeadibe T.C., Ajaero C.K., Okonkwo E.E., Okpoko P.U., Akukwe T.I., Njoku-Tony F. 2015. Integrating community perceptions and cultural diversity in social impact assessment in Nigeria. Environ. Impact Asses., 55, 74-83.

Oldekop J.A., Holmes G., Harris W.E., Evans K.L. (2016). A global assessment of the social and conservation outcomes of protected areas. Conserv. Biol. 30, 133-141.

Paleczny, D., Harhash, K.A. 2007. The state of Ras Mohammed National Park, an evaluation of management effectiveness. Egyptian-Italian environmental cooperation programme, nature conservation sector capacity building project: Cairo.

Pomeroy, R.S., Parks, J.E., Watson, LM. 2004. How is your MPA doing? A guidebook of natural and social indicators for evaluating Marine Protected Area Management effectiveness. Gland, Switzerland and Cambridge UK: IUCN.

Pullin A.S., Bangpan M., Dalrymple S., Dickson K., Haddaway N.R., Healey J.R., Hauari H., Hockley N., Jones J.P.G., Knight T., Vigurs C., Oliver S. 2013. Human well-being impacts of terrestrial protected areas. Environ. Evid., 2, 19.

Putnam, R.D., Leonardi, R., Nanetti, R.Y. 1993. Making Democracy Work: Civic traditions in modern Italy. New Jersey: Princeton University Press.

Rees, S.E., Rodwell, L.D., Searle, S., Bell, A. 2013. Identifying the issues and options for managing the social impacts of Marine Protected Areas on a small fishing community. Fish Res., 146, 51-58.

Schreckenberg, K., Camargo, I., Withnall, K., Corrigan, C., Franks, P., Roe, D. et al. 2010. Social Assessment of Conservation Initiatives: A review of rapid methodologies. Natural Resource Issues No. 22. London: IIED.

Sims KRE. 2010. Conservation and development: Evidence from Thai protected areas. J. Environ. Econ. Manage., 60, 94-114;

Soares-Filho, B., Paulo Moutinho, P., Nepstad, D., Anderson, A., Rodrigues, H., Garcia, R. et al. 2010. Role of Brazilian Amazon protected areas in climate change mitigation. Proc. Natl. Acad. Sci. U.S.A, 24, 10821-10826.

Staub, F., Hatziolos, M.E. 2004. Score Card to Assess Progress in Achieving Management Effectiveness Goals for Marine Protected Areas. World Bank.

Struhsaker TT, Struhsaker P.J., Siex K. 2005. Conserving Africa's rain forests: problems in protected areas and possible solutions. Biol. Conserv., 123, 45-54

Stevenson, T.C., Tissot, B.N., Walsh, W.J. 2013. Socioeconomic consequences of fishing displacement from marine protected areas in Hawaii. Biol. Conserv., 160, 50-58. 
640

641

642

643

644

645

646

647

648

649

650

651

652

653

654

655

656

657

658

659

660

661

662

663

664

665

666

667

668

669

670

671

Stoll-Kleemann S., de la Vega-Leinert A.C., Schultz L., 2010. The role of community participation in the effectiveness of UNESCO Biosphere reserve management: evidence and reflections from two parallel global surveys. Environ. Conserv., 37, 227-238.

Stolton, S., Hockings, M., Dudley, N., MacKinnon, K., Whitten, T., Leverington, F. 2007. Management Effectiveness Tracking Tool: Reporting Progress at Protected Area Sites. Second Edition. Gland, Switzerland: WWF International.

Tempesta, M., Otero, M. 2013. Guide for quick evaluation of management in Mediterranean MPAs. WWF Italy, IUCN.

Vanclay, F. 2003. International Principles for Social Impact Assessment. Impact Assess. Proj. Apprais., 21, 5-12.

Vanclay, F. 2012. The potential application of Social Impact Assessment in integrated coastal zone management. Ocean Coast. Manage., 68, 149-156.

Vanclay F. with Esteves A.M., Aucamp I., Franks D.M. 2015. Social Impact Assessment: Guidance for assessing and managing the social impacts of projects. International Association for Impact Assessment. Available at: http://www.iaia.org/uploads/pdf/SIA_Guidance_Document_IAIA.pdf

Vandeperre, F., Higgins, R.M., Sanchez-Meca, J., Maynou, F., Goni, R., Martin-Sosa, P., Perez-Ruzafa, A., Afonso, P., Bertocci, I., Chec’hriou, R., D’Anna, G., Dimech, M., Dorta, C., Esparza, O., Falcon, J.M., Forcada, A., Guala, I., La Direach, L., Marcos, C., OjedaMartinez, C., Pipitone, C., Schembri, P.J., Stelzenmuller, V., Stobart, B. \& Santos, R.S. 2011. Effects of no-take area size and age of marine protected areas on fisheries yields: a metaanalytical approach. Fish Fish., 12, 412-426.

Vokou D., Dimitrakopoulos P.G., Jones N., Damialis A., Monokrousos N., Pantis J.D., Mazaris A.D. et al. 2014. Ten years of co-management in Greek protected areas: an evaluation. Biodivers. Conserv., 23, 2833-2855

Voyer, M., Gladstone, W., Goodall, H. 2012. Methods of social assessment in Marine Protected Area planning: Is public participation enough? Mar. Policy, 36, 432-439.

Wells, S., Mangubhai, S. 2004. A Workbook for Assessing Management Effectiveness of Marine Protected Areas in the Western Indian Ocean. Nairobi, Kenya: IUCN Eastern African Regional Programme.

West, P., Igoe, J., Brockington, D. 2006. Parks and Peoples: The Social Impact of Protected Areas. Annu. Rev. Anthropol. 35, 251-277. 
672 Wolf, J., Adger, N.W., Lorenzoni, I., Abrahamson, V., Raine, R. 2010. Social capital, 673 individual responses to heat waves and climate change adaptation: An empirical study of two 674 UK cities. Global Environ. Chang., 20, 44-52.

675

676 
